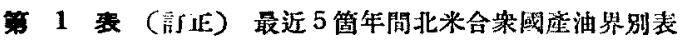

\begin{tabular}{|c|c|c|c|c|c|c|}
\hline & & 1934 & 1935 & 1936 & 1937 & 1938 \\
\hline \multirow{2}{*}{ 古 生 界 } & $\begin{array}{l}\text { 座額 } \\
(千 \text { 鸣 })\end{array}$ & 391,841 & $.422,639$ & 460,014 & 531,909 & 476,849 \\
\hline & $\%$ & 43 & 43 & 42 & 42 & 40 \\
\hline \multirow{2}{*}{ 中生 界 } & 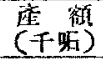 & 245,947 & 241,480 & 256,984 & 288,092 & 265,736 \\
\hline & \%ó & 27 & 24 & 23 & 23 & 22 \\
\hline \multirow{2}{*}{ 新 生 界 } & 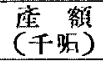 & 270,294 & 332,280 & 379,954 & 452,449 & 464,656 \\
\hline & $\%$ & 27 & 33 & 35 & 35 & 38 \\
\hline \multirow{2}{*}{ 合 筷 } & $\begin{array}{l}\text { 网 } \\
(\text { 千額 }\end{array}$ & 908,082 & 996,399 & $1,096,952$ & $1,272,450$ & $1,207,241$ \\
\hline & $\%$ & 100 & 100 & 100 & 100 & 100 \\
\hline
\end{tabular}

\title{
掘燯泥水測定法
}

日本石油株式筜篗 鐄 部

\section{(1) 試料の珠取}

\section{I. 理溫泥水测定法}

泥水試料は原則としてマッドスクリーン通過後に於いて探取するるのとす。但し泥 水の比電及び粘度の測定はマッドスクリーン通過前及び後に於いてて掫せる試料につ きて夫及行ふすのとす。

\section{[2] 比重の湘定}

1. 泥水の比重は比需瓶による重量测定方法またはハイドロメーターを使肋する。

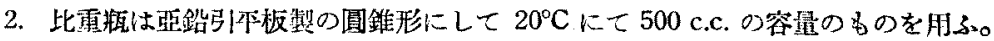

3. 比重瓶に試料を先し，且付桿䄮にてその重量を湘り，以て比重を算山する。

4. Мイドロメーターはバロイド式のるのを肪ふ。

5. ハイドロメーターの下端のベークライト・キャッブを捻子外し，これに泥水を无 せる後再び捻子付け，その外側につきたる垱水をよく拭ひ取る。

6. ハイドロメーターのケースに菬水を充し，この中にハイドロメーターを浮かせ， 水面に接与る部分のメーダーの日盛を以て比重を筧む。

7. 此雷は小數第 2 位まで求さるものとす。

\section{(3) 粘速の測定}

1. マーシュ・フォンネル・ビスコシメーターを伐䏳す。

2. ピスコシメーダーに泥水 500 c.c. を入れ，その流出するに努する时間秒を以て 
泥水の粘速を坟す。但し粘魀 60 秒を超える泥水についてはメーターに泥水 1,500 c.c. を入れてその 1,000 c.c. の流出するに荘する時間秒を以て粘速を蒜すすのとす。

3. 本ファンネル・メーターは $20^{\circ} \mathrm{C}$ にて声水 500 c.c. 入れたるとき, その流出寸る に要する時間が 18.5 秒なるにつき，ときどき清水にて檢查修正するを要す。

4. 泥水の粘速は溫度及び靜止特間によりて著しく綴化するものなるにつき，でき


征す。

\section{[4] 1-ルド・バリューの測定}

1. シアロメーターまたはストーマー粘度計を朋ふ。

2. シアロメーターーを泥水中に自重にて溉降すると感ずるまで指にて茂へて靜かに 沈降せしめ, 重みを感しなななつたときに指を離し，それから 30 秒經過せるとき泥 水中より弓揚ぐ。

3. シアロメーターの泥水面より上に殘りたる部分の長さ粍を以てイールド・パ ニーの値とす。但し特に絕對値を要求する場合は別表に上り瓦每平方糎にて值を求め 万。

4. シアロメーターには大小の 2 種あり。

5. 原則として小シアロメーターを使用するものとす。

6. 特殊坑茾にて 濃厚なる泥水を使用与る場合, そのイールド・バリューの測定には 大シアロメーターを使朋し，その旨特訅するるのとす。

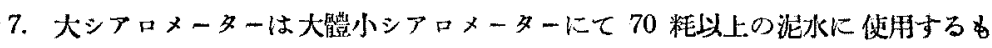
のとす。。

8.ストーマー粘度計は主として就驗空に於いて州ふっ

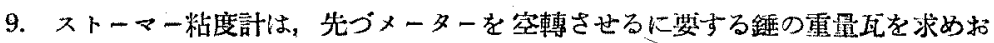

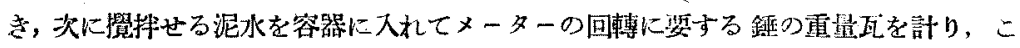
れ上り空轉に要せる瓦數を減して值を求む。

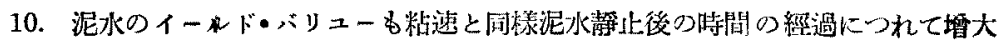
するむのなるにつき, 靜止後短時間內に測定するやう手早く行ふを要す。

\section{[5] 䀩化度の測定}

1. シアロメーターまたはストーマー粘度計を们ふ。

2. シアロメーターーによるときには泥水を㩭拌面後に澌它せるイールド・゙リューと, この泥水をそのま〉静止せしめ 10 分間後に㧶び测定せるイールド・バリューとを比 較して膠化の程度を求める。

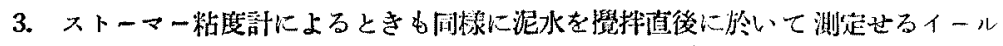

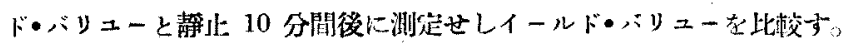




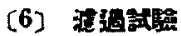

1. シシロイド式ウォールビルデング・テスターを伐用す。

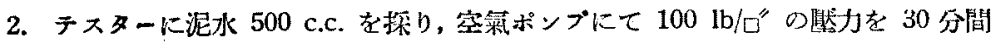
がてテストを用S。

3. 㴔過されし水は 100 c.c. のメスシリンダーに受けて c.c.にて計量し, 濾紨上 に形成されるマッドケーキはその厚さを㮽單仙にて数す。

\section{[7] 杪分の測定}

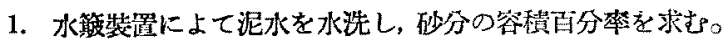

2. 泥水 75 c.c. 老湘定用メスシリンダーに探り, 溜水を归へて總量を 250 c.c. と

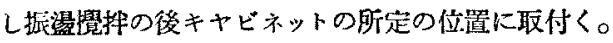

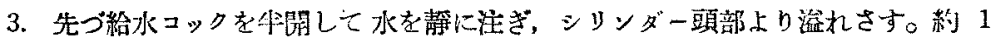
分の後コックを全開してシリンダー內に注入し，そのまっにて 30 分間水洗を行ふ。

4. 給水を此めたる後シリンダーを暫く靜止させ，その底に沈栍せる秒粏の容積百

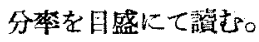

\section{[8] 整分の瑯定}

1. 泥水を濾過して得たる憈水を嘼料とす。

2. 試料 5 c.c. を正確にビペットにて吸ひ取りて 100 c.c. 大の三鬥フラスコまたは ビーカーに入れ，蒸溜水約 5 c.c. を加へ，クロム酸加里溶液を指摹として 1 源加ふれ ば液は䔮色となる。

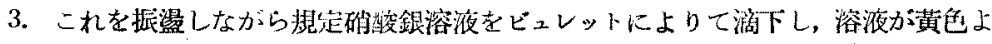



4. 次の式により㴔水 11 中に念有せられる酤分を $\mathrm{mg}$ にて求む。 留分 $\mathrm{mg}=$ 碓酸銀溶液消费量 c.c. $\times 200$

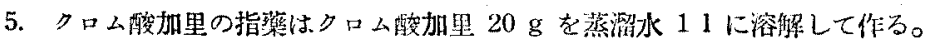

6. 規定硝酸领溶液は硝酸銀 $2.907 \mathrm{~g}$ を 11 の蒸溜水に溶解せるものにして, 褐色

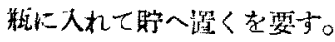

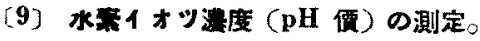

1. 水素イォン偖または $\mathrm{pH}$ テトドーパーを俅肞す。

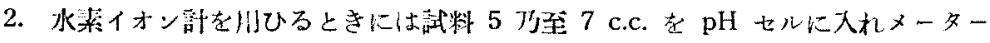
の指針によつて $\mathrm{pH}$ 價を嫍む。

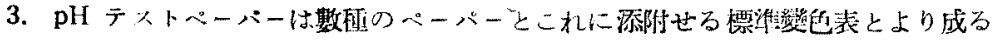
を以て近笛なるテストハーパーを筫翋してデストを们ふ。

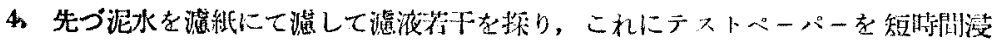

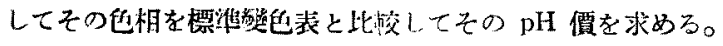




\section{〔10]コロ1ド含有盢の則定。}

1. 簡便方法としては泥水の沈澱によるコロイド訊驐を行ふ。

2. 毊付 100 c.c. 入メスシリンダーに泥水 100 c.c. を探り，これを裂水にて 100

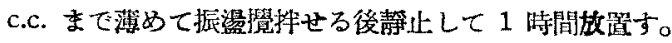

3. 粗惡なる泥水は上澄の液が短時間にて唀明となり，コロイド含有量大なる泥水 ほど混濁の程度大なり。

4. 精密にコロイド分を測定するには遠心分離器によりコロイド分を分㒕して科量 しての重㬈 \%を求む。

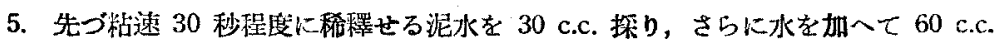
上守。

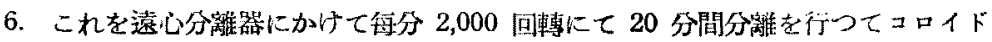
分と非コロイド分とを分離する。

7. 容器を傾倒せる際流出する部分をコロイド分とし, 流出せざる部分を非コロイ ド分としてこれを別丈に蒸發且に探り蒸發郣固して重量を测定する。

8. コロイド分の重量を $W_{1}$ とし, 非コロイド分の重量を $W_{2}$ とすればコぬイド分 の含有 \%は

$$
\frac{W_{1}}{W_{1}+W_{2}} \times 100
$$

\section{[1] 試䉽の操取}

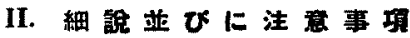

1. 試料はディッチの流れの机部にて掓收すへきも，若し適當なる落口あればそ こにで抹收すれば理想的なり。

2. 泥水は租砂及びガス等を除去したるるのにつきてその性賀を測定子るを原則と し，そのためマッドスクリーン通過後に扲いて試料 を探收すんきも坑历排出の泥水杜局力の計算または 粘速等を测定せんとする埸合にはマッドスクリーン通 過前の欲料につきて测主を行ふて装す。よて泥水比 重及び粘速につきてはマッドスクリーン通過の前及 び後に於いて夫ふ測它することとせり。

\section{(2) 比重の澌定}

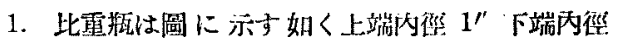

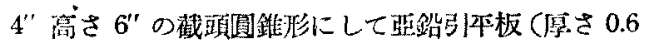

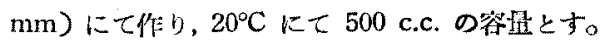

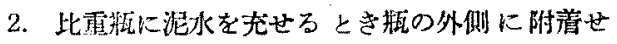
る泥水は丁郂に拭ひとる。

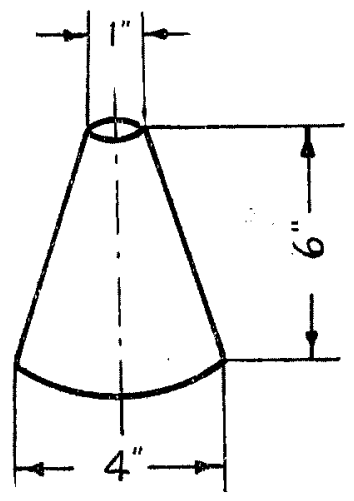


3. ハイドロメーターの下端のベークライト・キャッブは谷量 50 c.c. てある。

4. ハイドロメーターを涌水中に浮かせる前にその外側に附着せる泥水を丁寧に拭 ひとること。

5. スクリーン通過前の泥水の比重については瓦斯含みのま〉これを測定すへさきで あるが，スクリーン通過後の泥水此重は棒にて充分に攪拌してガス泡を拢去つた後に 測定すべきである。

\section{〔3]粘速の測定}

1. マーシュ・ファンネラメーターは圖の如き寸法に作り, 便宜上谷量 1,500 c.c. の

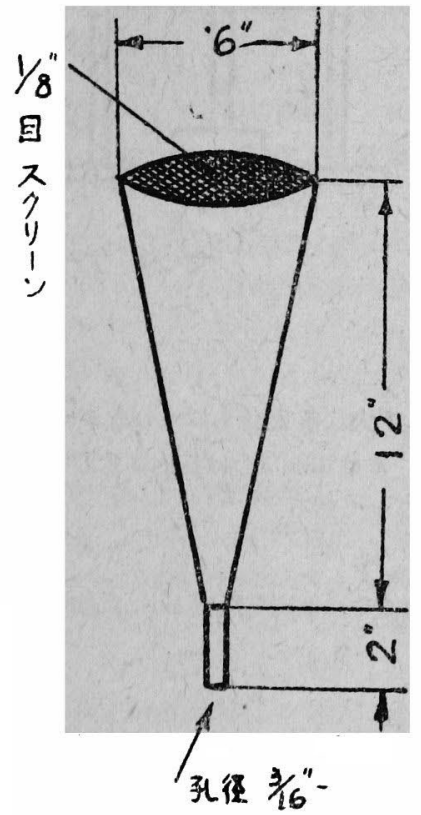
ところに目盛を附す。

2. メーターに泥水を注入する際に $1 / 8^{\prime \prime}$ 目の スクリーンを通すこと。

3.メーターを修正する場合にはメーター一 端に取付けたる銅パイブをその全長に沿ひ本均 に內巠を削り攄げまたは絞り縮むること。特に その尖端の一部分のみ絞り縮むる如きことは絕 對に避くること。

4. ファッネルメーターの测定時間の最終點 はチューブより流出する泥水の流れが切れたる 瞬間時を以てし，點滴狀に流出する 時間は除外 すること。

\section{[4] イールド・バリューの測定}

1. 大シアロメーターは厚さ $1 \mathrm{~mm}$ 長さ 150 $\mathrm{mm}$ 巾 $100 \mathrm{~mm}$ のアルミニゥム板を丸めて, 商さ $100 \mathrm{~mm}$ 淔荭約 $48 \mathrm{~mm}$ の圓筒に作りた るすのにして重量を $42 \mathrm{~g}$ とする。

2. 小シアロメーターに內德 $30 \mathrm{~mm}$ 高さ 100 $\mathrm{mm}$ 厚さ約 $0.5 \mathrm{~mm}$ のアルミニゥム製嫃筒に して重量を $8 \mathrm{~g}$ とする。

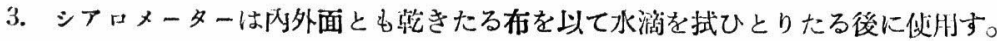
4. シアロメーターの㳐降方法は本交訅載の如く静かにこれを行ひ, 彈みをつけて 沈降せしめぬやう注意すること。沈降中多少傾科するときは指にて輕く水平に押して これを概略鉛四になほすこと。

5. シアロメーターの泥水渡漬面は多少はメーターに對して傾科するものなるによ

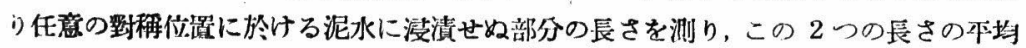


を以てイールドバリューの值とすること。

6. イールドベリュー測定用の泥水容器として位 $10 \mathrm{~cm}$ 高さ $20 \mathrm{~cm}$ 底つきの圆 筒を用意しおけば便利なり。

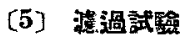


すきすのを健用するが良し。但し比較的强勒なるものが可なり。

2. 緊力は常に一定に保つ如く注意ること。

3. 形成せられたるマッドケーキの厚さは吹 の如くにして测定す。先づ圖に亦す如く直丝 1 $\mathrm{cm}$ 長さ $15 \mathrm{~cm}$ 网端面截邀せる重量約 $95 \mathrm{~g}$ の

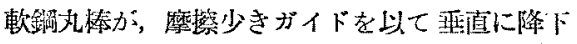
する如き裝置を侦用す。マッドケーキを濾紙と


ドヶーキの奉面に靜かに降下せしめたるときそ の下端面が自然に静止せる住置を以てマッドケ 一キの上面とす。下面は濾組面なり。よつてこ

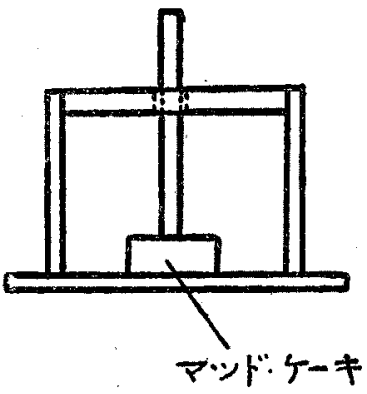
の雨面に於ける丸棒のガイドに對する估㯰上り マッドケーキの㻺さを测定す。

4. 濾壁の厚さ及び濾水の量は泥水溫度によりて大なる變化あるすのなるにつき， 北驗を行ひたるときの泥水㴘度を明記するを要す。なほ可能ならば抗入泥水溫度に近

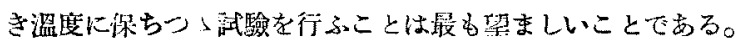

\section{[6] 砂分の則定}


水の水頭の變化せざるや弓注意を装す。

\section{[7] 媐分の測定}

1. 規定㗂酸銀溶液 1 c.c.は $1 \mathrm{mg}$ の篮化ナトリウムに相當するものなり。

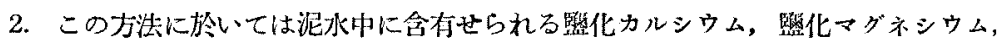



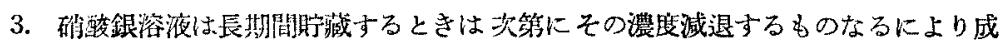

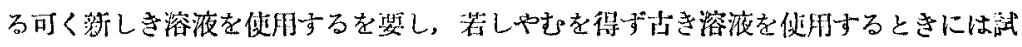

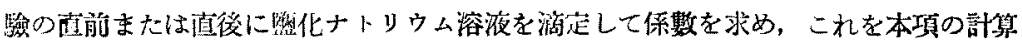
倠に乘ず。

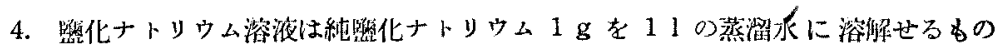
にして、この 10 c.c. をと゚ペットにてフラスさまたはビーカーに㨲りこれを矿酸銀溶液 
にて滴定して次式によつて係僌を求める。

$$
\text { 係數 }=\frac{10}{\text { 硝醉銀溶液消費量 c.c. }}
$$

以上

\section{細拉堆皘物の沈皘に及ほすイオンの影響}

森本是平

（原文は Am. Jour. Sci. Vol. 239, No. 10, Oct. 1941 に揭数の L. R. Dreves. kracht 及び G. A. Thiel 共㛭の Ionic Effects on The Rate of Settling of Finegrained Sediments.)

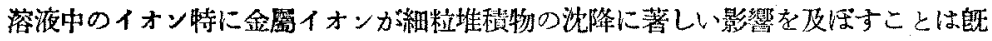

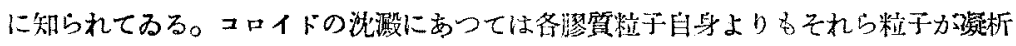

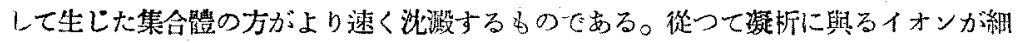
䊀水成岩の生成に雷要な役制をなすことも明らかである。また他の條件がずへて等し

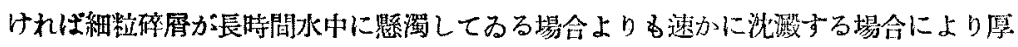

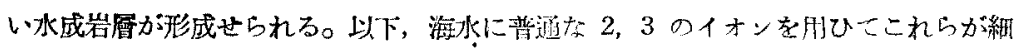

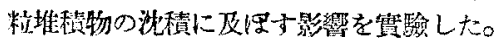

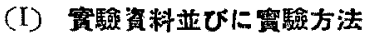

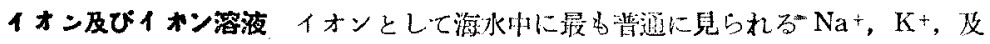
び $\mathrm{Mg}^{++}$を遙んだ。天然水には3價のイオン合まれてるるが期に際してはこれ

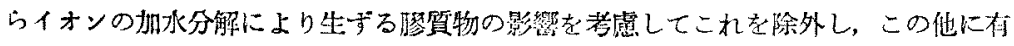



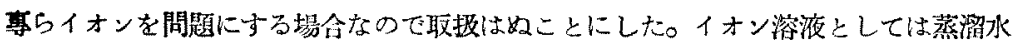

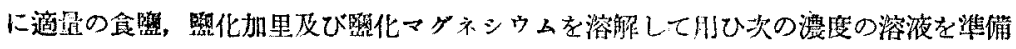
Lた。

\begin{tabular}{|c|c|c|c|c|c|}
\hline \multicolumn{2}{|c|}{$\mathrm{NaCl}$} & \multicolumn{2}{|c|}{$\mathrm{KCl}$} & \multicolumn{2}{|c|}{$\mathrm{MgCl}_{2}$} \\
\hline $1=$ & 溶液 & 1 & 一溶液 & & 溶液 \\
\hline 0.5 & $"$ & 0.5 & $"$ & 0,5 & $"$ \\
\hline 0.1 & $"$ & 0.1 & $"$ & 0.1 & $"$ \\
\hline 0.03 & $"$ & 0.03 & " & 0.03 & $"$ \\
\hline 0.02 & $"$ & 0.02 & $t$ & 0.02 & $"$ \\
\hline 0.01 & $"$ & 0.01 & $"$ & 0.01 & $"$ \\
\hline
\end{tabular}

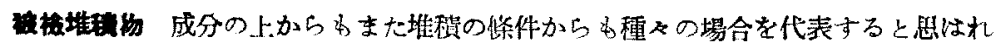

